\title{
Effect of a natural versus a synthetic antioxidant, and sex and age on the redox profile in the blood of growing turkeys
}

\author{
K. Ognik", A. Czech \& K. Stachyra \\ Department of Biochemistry and Toxicology, Department of Biology and Animal Production, University of \\ Life Sciences in Lublin, Poland, Akademicka 13, 20-950 Lublin
}

(Received 15 January 2013; Accepted 6 June March 2013; First published online 19 December 2013)

Copyright resides with the authors in terms of the Creative Commons Attribution 2.5 South African Licence.
See: http://creativecommons.org/licenses/by/2.5/za
Condition of use: The user may copy, distribute, transmit and adapt the work, but must recognize the authors and the South African Journal of Animal
Science.

\begin{abstract}
An investigation was conducted with turkeys during the spring-summer seasons of 2008 to 2011. Each season the turkeys were allocated to three treatments. The control received a standard compound feed. In the second treatment, a natural feed additive, consisting of 5\% extracted polyphenols from Cynara scolymus, was included in the diet, and the third consisted of a synthetic antioxidant mixture containing $17 \%$ butylhydroxytoluene (BHT), 6\% propyl gallate, $2.4 \%$ etoxyquin and $25 \%$ citric acid. Blood samples were collected from the brachial vein, and antioxidative parameters were measured in the plasma. The males in the study had a significantly higher concentration of peroxides, malondialdehyde and vitamin $\mathrm{C}$ in their plasma than the females. The plasma concentration of low-molecular antioxidants, as well as the activity of the antioxidative enzymes, decreased with the age of the birds. The inclusion of the natural and synthetic feed additives to the diet increased the levels of the ferric-reducing ability of plasma and of vitamin $\mathrm{C}$ in turkeys.
\end{abstract}

Keywords: Cynara scolymus, polyphenols, FRAP, vitamin C, free radicals

\#Corresponding author: kasiaognik@poczta.fm

\section{Introduction}

A measure of the antioxidant status of the body is the so-called balance or ratio between oxidative factors. These include lipid peroxidation products (conjugated dienes, peroxide radicals, hydroperoxides of fatty acids, and alkyl radicals), endogenous and exogenous suppressive substances against radicals (ROS) such as special groups of enzymes, for example superoxide dismutase, glutathione peroxidase, catalase with their associated metal cations ( $\mathrm{Cu}, \mathrm{Zn}, \mathrm{Mn}, \mathrm{Fe}$ ) and anion, selenium; and many low-molecular antioxidants such as bilirubin, creatinine, uric acid, urea, glutathione and active forms of vitamins E and C, (Bartosz, 2004). All these constitute the total antioxidative potential of blood plasma, referred to as the ferric-reducing ability of plasma (FRAP) (Bartosz, 2004; Lutnicki et. al., 2006). Multiple continuous oxidative processes at cellular and tissue level in the body of animals as a result of catabolism and the activity of selected forms of immune cells are normal physiological processes. They are counterbalanced by a complex antioxidative mechanism aimed at minimizing the effects of the so-called free radical species to maintain optimal homeostasis in the body, the antioxidant balance (Serafini \& Del Rio, 2004). As a result of the exposure of the animal body, including that of birds, to stress-inducing factors, immunosuppressive factors and a high level of cell metabolism owing to conditions and specific characteristics of rearing (stocking density, exchange and temperature of air, epizootic factors, genetic potential), a frequent phenomenon observed in the commercial rearing of poultry is the destabilization of the antioxidative balance owing to the excessive activity of free radical species (Truchliński et. al., 2007, Ognik \& Sembratowicz, 2012).

The efficacy of antioxidative defence mechanisms is not a constant function, as it may be affected by the sex and age of the animal (Wang et al., 1998; Wickens, 2001; Milinković-Tur et al., 2007; Farahat et al., 2008b; Milinković-Tur et al., 2009). Modulation of the antioxidative status of the bird's body through 
specified treatments, including optimizing the level and quality of the diet, and selecting nutrients and functional components, may be one of the key and highly effective means of improving the efficiency of the antioxidative system and, thereby, the health status of poultry.

The aim of this study was to determine how antioxidant supplements in the diet and the age and sex of the birds influence the development of indicators of redox status in the blood of growing turkeys.

\section{Materials and Methods}

The investigation was carried out with the approval of the local ethical committee (LEC 2008-2011). The study was performed to evaluate the effect of selected antioxidative feed additives, as well as age and sex changes, in the redox characteristics in the blood of growing turkeys. The study was conducted in the spring-summer seasons of 2008 to 2011. In each season, the experiment was conducted on 360 (3 group x 120 birds) tom turkeys and 360 (3 group x 120 birds) hen turkeys of the Big 6 line. Each treatment with 120 birds contained six replicates of 20 birds. The control, Group I, received a standard compound feed formulated according to NRC (1994) recommendations. The diet contained synthetic dl-alpha-tocopherol acetate at a dietary level of $50 \mathrm{mg} / \mathrm{kg}$ from 1 to 9 weeks of age and $45 \mathrm{mg} / \mathrm{kg}$ from week 10 onwards. The diet of Group II contained natural feed additives, 5\% extracted polyphenols from Cynara scolymus, and that of Group III a synthetic feed additives containing synthetic antioxidants: 17\% butylhydroxytoluene (E321), 6\% propyl gallate (E310), 2.4\% etoxyquin (E324) and 25\% citric acid (E330) (Table 1). The feed additives were added to the diets from the 5th to 16th week of the study.

Table 1 Experimental treatments and allocation of birds in 2008, 2009, 2010, 2011

\begin{tabular}{|c|c|c|c|}
\hline \multirow[b]{2}{*}{ Sex turkey } & \multicolumn{3}{|c|}{ Experimental treatments } \\
\hline & $\begin{array}{c}\text { I } \\
\text { Control }\end{array}$ & $\begin{array}{c}\text { II } \\
5 \% \text { extracted } \\
\text { polyphenols } \\
200 \mathrm{~g} / \mathrm{t}\end{array}$ & $\begin{array}{c}\text { III } \\
\text { Synthetic antioxidants } \\
200 \mathrm{~g} / \mathrm{t}\end{array}$ \\
\hline Toms (360 birds) & $\begin{array}{c}120 \\
(6 \times 20) \\
120 \\
(6 \times 20)\end{array}$ & $\begin{array}{c}120 \\
(6 \times 20) \\
120 \\
(6 \times 20)\end{array}$ & $\begin{array}{c}120 \\
(6 \times 20) \\
120 \\
(6 \times 20)\end{array}$ \\
\hline
\end{tabular}

All birds were healthy and kept in cages $2.5 \mathrm{~m} \mathrm{x} 4 \mathrm{~m}$ (20 hens) and $3 \mathrm{~m} \mathrm{x} 5 \mathrm{~m}$ (20 toms) in size, in zootechnical conditions appropriate for turkey fattening. In each experiment, the turkeys were reared in the same poultry house. The birds were fed ad libitum and had freely accessible drinking water. The feed mixtures were produced on the farm, based on the recipes and premixes of the Polsanders-Poland company, and consisted of wheat, maize meal, extracted soybean meal and soybean oil, and maintained on an isonitrogenous and isoenergetic basis (Table 2). In computing the diet, consideration was given to other components affecting the antioxidative status of the body, such as vitamin $\mathrm{C}$ and selenium. Additional vitamin $C$ was not supplied in the vitamin/mineral supplement, Farmix, nor was vitamin $C$ added to the drinking water. The level of selenium during the rearing periods was as follows: Starter $-0.352 \mathrm{mg} / \mathrm{kg}$, Grower I - $0.371 \mathrm{mg} / \mathrm{kg}$, Grower II - $0.370 \mathrm{mg} / \mathrm{kg}$; Grower III - $0.374 \mathrm{mg} / \mathrm{kg}$; Finisher I - $0.319 \mathrm{mg} / \mathrm{kg}$ and Finisher II $-0.300 \mathrm{mg} / \mathrm{kg}$.

During the 9th week of an experiment, 72 hens (24 birds $\mathrm{x} 3$ group) and 72 toms (24 birds $\mathrm{x} 3$ group) were randomly selected for blood collection. The same birds were bled again in their 12th and 15th weeks of age. Spectrophotometric assays were used to determine antioxidative enzymes activities in the plasma: Superoxide dismutase (SOD, E.C. 1.15.1.1) activity was determined using the adrenaline method modified to be read at $320 \mathrm{~nm}$ (Bartosz, 2004), and catalase (CAT, EC 1.11.1.6) activity was assayed according to Bartosz (2004). Assays to measure the antioxidant status were conducted to calculate the ferric-reducing ability of plasma (FRAP) (Benzie \& Strain, 1996). Vitamin C concentration was obtained using the method of Omaye et al. (1979), and glutathione (GSH+GSSG) activity according to Akerboom \& Sies (1981) and 
Weitzel et al. (1989). In addition, the plasma was analysed for concentrations of lipid peroxidation products: peroxides $\left(\mathrm{H}_{2} \mathrm{O}_{2}\right)$, according to the method of Gay \& Gębicki $(2000 ; 2002)$, and malondialdehyde (MDA) as the end product of tissue lipids oxidation, according to Salih et al. (1987).

Table 2 Ingredient and nutrient content of standard diets

\begin{tabular}{|c|c|c|c|c|c|c|}
\hline & \multicolumn{6}{|c|}{ Feeding period (in weeks of age) } \\
\hline & $\begin{array}{l}\text { Starter } \\
\text { (1-2 wk ) }\end{array}$ & $\begin{array}{l}\text { Grower I } \\
\text { (3-5 wk ) }\end{array}$ & $\begin{array}{c}\text { Grower } \\
\text { II } \\
\text { (6-9 wk ) }\end{array}$ & $\begin{array}{c}\text { Grower } \\
\text { III } \\
\text { (10-12 wk) }\end{array}$ & $\begin{array}{l}\text { Finisher I } \\
(14-16 \text { wk) }\end{array}$ & $\begin{array}{c}\text { Finisher II } \\
\text { (over } 16 \text { wk ) }\end{array}$ \\
\hline \multicolumn{7}{|l|}{ Ingredient } \\
\hline Maize meal (g/kg) & 256 & 274 & 238 & 352 & 474 & - \\
\hline Wheat (g/kg) & 200 & 250 & 300 & 250 & 250 & 725 \\
\hline Rape cake (g/kg) & - & - & - & - & - & 85.0 \\
\hline Wheat bran (g/kg) & 30 & - & - & - & - & - \\
\hline $\begin{array}{l}\text { Soybean meal } \\
46 \% \text { protein }(\mathrm{g} / \mathrm{kg})\end{array}$ & 410 & 417 & 388 & 327 & 204 & 100 \\
\hline $\begin{array}{l}\text { Soybean meal } \\
45 \% \text { protein }(g / k g)\end{array}$ & 20 & - & - & - & - & - \\
\hline Fish meal $60 \%,(\mathrm{~g} / \mathrm{kg})$ & 35 & - & - & - & - & - \\
\hline Fodder chalk (g/kg) & 12 & 17 & 17 & 14 & 15 & 13 \\
\hline Soybean oil (g/kg) & 5 & 10 & 25 & 30 & 30 & 50 \\
\hline Cytromix Plus $^{1}$ (g/kg) & 2 & 2 & 2 & 2 & 2 & 2 \\
\hline $\operatorname{Farmix}^{2}(\mathrm{~g} / \mathrm{kg})$ & 0 & 30 & 30 & 25 & 25 & 25 \\
\hline \multicolumn{7}{|c|}{ Nutrient composition (calculated) } \\
\hline Crude protein, g/kg & 271.0 & 255.0 & 245.0 & 220.0 & 175.0 & 265.0 \\
\hline $\mathrm{ME}, \mathrm{MJ} / \mathrm{kg}$ & 11.45 & 11.73 & 12.19 & 12.58 & 13.09 & 13.39 \\
\hline Crude fibre (g/kg) & 28.6 & 27.7 & 27.2 & 27.1 & 27.0 & 42 \\
\hline Lysine (g/kg) & 18.1 & 17.1 & 15.7 & 13.8 & 11.7 & 12.0 \\
\hline Meth.+ cyst. (g/kg) & 9.8 & 9.0 & 8.8 & 7.9 & 7.0 & 8.0 \\
\hline Tryptophan (g/kg) & 3.4 & 2.8 & 2.7 & 2.3 & 1.9 & 2.2 \\
\hline Arginine (g/kg) & 17.7 & 15.7 & 15.0 & 13.2 & 9.8 & 12.0 \\
\hline Calcium (g/kg) & 13.9 & 12.3 & 11.7 & 10.6 & 9.4 & 11.0 \\
\hline Avail P (g/kg) & 7.7 & 6.7 & 5.9 & 5.7 & 4.7 & 5.0 \\
\hline Sodium (g/kg) & 1.5 & 1.6 & 1.5 & 1.5 & 1.5 & 1.6 \\
\hline
\end{tabular}

Results were subjected to statistical procedures using the analysis of variance with the least square method (SAS, 1996) for the following model:

$\mathrm{Y}_{i j k l m}=\mu+\mathrm{A}_{i}+\mathrm{S}_{j}+\mathrm{D}_{k}+\mathrm{R}_{l}+\mathrm{e}_{i j k l m}$

where:

$\begin{array}{ll}Y_{i j k l m} & \text { value of parameter } \\ \mu & \text { mean of all assay } \\ A_{i} & \text { effect of age }\end{array}$




$\begin{array}{ll}S_{j} & \text { effect of sex } \\ D_{k} & \text { effect of dietary } \\ Y_{l} & \text { effect of the year of the study } \\ e_{i j k l m} & \text { random error }\end{array}$

\section{Results and Discussion}

This investigation demonstrated that the administration of both natural and synthetic feed additives with antioxidative or potentially antioxidative properties to turkey diets resulted in increased $(P \leq 0.01)$ plasma concentrations of the non-enzymatic antioxidants FRAP and vitamin C (Table 3). Furthermore, the application of the natural feed additive decreased $(P \leq 0.05)$ the activity of CAT in blood plasma of the birds and the synthetic feed additives reduced $(P \leq 0.01)$ the plasma concentration of lipid peroxides.

Table 3 Effect of dietary (D) inclusion of a natural or synthetic feed additive on antioxidative and oxidative parameters in blood plasma of turkeys

\begin{tabular}{|c|c|c|c|c|c|}
\hline \multirow[b]{2}{*}{ Treatments } & \multicolumn{5}{|c|}{ Antioxidative parameters $(\mathrm{LSM} \pm \mathrm{SE})$} \\
\hline & $\begin{array}{l}\text { SOD } \\
\text { U/mL }\end{array}$ & $\begin{array}{c}\text { CAT } \\
\text { U/mL } \\
\end{array}$ & $\begin{array}{c}\text { FRAP } \\
\mu \mathrm{mol} / \mathrm{L}^{-}\end{array}$ & $\begin{array}{l}\text { VIT.C } \\
\text { mg/L }\end{array}$ & $\begin{array}{c}\text { GSSG+GSH } \\
\mu \mathrm{mol} / \mathrm{L}\end{array}$ \\
\hline \multirow[b]{3}{*}{ II } & $\begin{array}{l}24.4^{\mathrm{ab}} \\
\pm 0.41\end{array}$ & $\begin{array}{c}4.49^{\mathrm{a}} \\
\pm 0.12\end{array}$ & $\begin{array}{c}63.0^{\mathrm{C}} \\
\pm 1.27\end{array}$ & $\begin{array}{c}0.158^{\mathrm{C}} \\
\pm 0.007\end{array}$ & $\begin{array}{c}0.174 \\
\pm 0.007\end{array}$ \\
\hline & $\begin{array}{r}24.0^{\mathrm{b}} \\
+0.37\end{array}$ & $\begin{array}{c}4.04^{\mathrm{b}} \\
+0.11\end{array}$ & $\begin{array}{r}74.6^{\mathrm{A}} \\
+1.09\end{array}$ & $\begin{array}{c}0.210^{\mathrm{A}} \\
+0.004\end{array}$ & $\begin{array}{c}0.162 \\
+0.003\end{array}$ \\
\hline & $\begin{array}{r}24.9^{\mathrm{a}} \\
\pm 0.55\end{array}$ & $\begin{array}{l}4.15^{\mathrm{ab}} \\
\pm 0.14\end{array}$ & $\begin{array}{r}68.7^{\mathrm{B}} \\
\pm 1.65\end{array}$ & $\begin{array}{c}0.179^{\mathrm{B}} \\
\pm 0.009\end{array}$ & $\begin{array}{c}0.164 \\
\pm 0.005\end{array}$ \\
\hline \multicolumn{6}{|c|}{ Oxidative parameters $(\mathrm{LSM} \pm \mathrm{SE})$} \\
\hline & $\begin{array}{r}\mathrm{H}_{2} \mathbf{O}_{2} \\
\mu \mathrm{mol} / \mathrm{L} \\
\end{array}$ & $\begin{array}{c}\text { MDA } \\
\mu \mathrm{mol} / \mathrm{L}\end{array}$ & & & \\
\hline I & $\begin{array}{l}5.39^{\mathrm{BC}} \\
\pm 0.14\end{array}$ & $\begin{array}{c}0.415 \\
\pm 0.049\end{array}$ & & & \\
\hline II & $\begin{array}{c}5.74^{\mathrm{AB}} \\
0.11 \pm\end{array}$ & $\begin{array}{c}0.378 \\
\pm 0.026\end{array}$ & & & \\
\hline II & $\begin{array}{l}5.25^{\mathrm{C}} \\
0.16 \pm\end{array}$ & $\begin{array}{c}0.411 \\
\pm 0.34\end{array}$ & & & \\
\hline
\end{tabular}

Treatment I: control; Treatment II: natural feed additives, 5\% extracted polyphenols from Cynara scolymus; Treatment III: synthetic feed additives containing synthetic antioxidants.

a,b,c. means within columns with no common superscript differ significantly at $P \leq 0.05$.

A,B,C : means within columns with no common superscript differ significantly at $P \leq 0.01$.

SOD: superoxide dismutase; CAT: catalase; FRAP: total antioxidant potential of plasma;

VIT.C: vitamin C; GSSG+GSH: glutathione total; $\mathrm{H}_{2} \mathrm{O}_{2}$ : peroxides: MDA: malondialdehyde.

Owing to the possibility of stimulating the antioxidative system through for instance an appropriate diet by including antioxidative additives to diets and the water, it is feasible in many cases to avoid or to reduce the effects of the oxidative stress in poultry (Table 3 ). The results of the reported study indicate that the application of both natural and synthetic feed additives with antioxidative or potentially antioxidative properties protects the body against induction of lipid peroxidation processes by stimulating the total antioxidative potential of plasma (FRAP). Ample data point to an increase in the level of FRAP and its constituents in turkeys receiving the natural additive (Ognik \& Sembratowicz, 2007; Ognik \& Czech, 2010a; b) or synthetic (Ognik \& Sembratowicz, 2011) additive with potential antioxidative properties through their feed or drinking water. Based on other studies, the increased level of low-molecular (nonenzymatic) antioxidants may result in the stimulation of the antioxidative enzymes, superoxide dismutase, 
peroxidise and catalase, (Kamel et al., 2003; Vara Prasad Reddy et al., 2009), which was not confirmed in the present investigation with turkeys.

Values depicting the direction of changes occurring in redox processes in blood plasma of turkeys are presented in Table 4. The effect of the sex of the turkeys on changes in prooxidative-antioxidative blood parameters demonstrated $(P \leq 0.01)$ a higher level of $\mathrm{H}_{2} \mathrm{O}_{2}$, MDA and vitamin $\mathrm{C}$ for turkey toms. Their blood plasma was also characterized by a lower $(P \leq 0.01)$ activity of SOD and total glutathione (GSSG+GSH). Higher concentrations of lipid peroxidation products and vitamin $C$ and lower concentrations of antioxidants (SOD and GSH) were recorded in the turkey toms than in the hens. It has been demonstrated that the efficiency of the antioxidative system in poultry is influenced, to a great extent, by the sex of the bird (Farahat et al., 2008b). According to Finley \& Kincaid (1991), sex determines the rate of metabolic transformations that effect changes in redox parameters. The physiological basis of the observed differences in the antioxidative parameters of animals of both sexes varies in intensity of oxidative stress and differs in response to that stress. This is linked with the mode of activation of the hypothalamic-pituitary-adrenal axis and the effect of the sex hormones. Farahat et al. (2008a; b) demonstrated that stress associated with the reproductive cycle causes females in the reproductive stage to require increased levels of antioxidative defence. In analysing the activities of selected antioxidative enzymes in chickens of both sexes, Farahat et al. (2008a; b) recorded higher levels in females than in males. However, owing to enhanced peroxidation of lipids observed in males, they seem to need a stronger stimulation of antioxidative defence (Gomez-Zubeldia et al., 2000). Nevertheless, those issues require further in-depth investigations, especially in poultry.

According to Table 3, a successive decrease with age in the activity of the antioxidative enzymes SOD and CAT, as well as MDA, is evident in both growing turkey hens and toms. In turn, analyses of the other antioxidative parameters in the blood of the turkeys (FRAP, vitamin C, GSSG+GSH, $\mathrm{H}_{2} \mathrm{O}_{2}$ ) demonstrated an initial increase until the 12th week of life, followed by a decrease in the 15th week. Investigations carried out with poultry, laboratory animals and humans have demonstrated that the activity of the antioxidative system, to some extent, is determined by age (Wang et al., 1998; Wickens, 2001; Milinković-Tur et al., 2007; Milinković-Tur et al., 2009). It has been proven that reactive oxygen species that induce cell damage and severe depletion of antioxidative defence elements accumulate in the course of body ageing (Sohal, 2002). Some works report a correlation between the antioxidative efficiency of a body and production performance parameters, that is, body weight and body weight gains of birds (La Vronga \& Combus, 1982). The analysis of the results of the present study demonstrated a step-wise decrease in the activity of the antioxidative enzymes along with the age of the turkeys. Generally, changes in the activity of antioxidative enzymes along with age in the case of poultry may exhibit two tendencies, ascending or descending (Gihan et al., 2009). The differences in activities of those enzymes, to a great extent, are determined by their sub-cellular localization. In some tissues, along with age, the peroxidation processes are observed to intensify, while others diminish (Tian et al., 1998). However, along with increasing age of poultry, often a decrease is first observed in activities of the antioxidative enzymes (SOD and CAT), followed by an increase, especially in laying hens in the period of peak egg production (Godin et al., 1995; Maini et al., 2007; Farahat et al., 2008b; Gihan et al., 2009). A decrease in the activity of an antioxidative enzyme (PGX) along with age of broiler chickens has been reported by Kamel et al. (2003). Interestingly, in the present study no increase with age was recorded in lipid peroxidation products of the turkeys. Verma et al. (2012) observed an increase in the level of lipid peroxidation products (MDA) with age, which was correlated with diminished activities of SOD and CAT. Decreasing activities of SOD and CAT during ageing are explained by the inactivation of these enzymes by increasing levels of $\mathrm{H}_{2} \mathrm{O}_{2}$ with increased age (Tian et al., 1998). However, apart from reactions of SOD with lipid peroxidation products, the reason for the decreasing activity of this enzyme might be reactions taking place in the process of non-enzymatic glycosylation, referred to as glycation. It has been demonstrated that enhanced glycation of SOD molecules resulted in the suppression of the activity of this enzyme in blood plasma along with age (Yan et al., 1997). Experiments conducted by Ehrenbrink et al. (2006) with rats indicate that along with age the activity of SOD decreased, which, however, was not correlated with increased levels of lipid peroxidation products. In turn, the initial increase observed in the present study of the ferric-reducing ability of plasma and its components (vitamin C and glutathione) 
Table 4 Antioxidative and oxidative parameters in blood of turkeys

\begin{tabular}{|c|c|c|c|c|c|c|c|c|c|c|}
\hline \multirow[b]{2}{*}{ Parameters } & & \multicolumn{2}{|c|}{ Sex (S) } & \multicolumn{3}{|c|}{ Age (A) } & \multicolumn{4}{|c|}{ Study year $(Y)$} \\
\hline & & $\begin{array}{c}\stackrel{9}{+} \\
\mathrm{n}=864\end{array}$ & $\begin{array}{c}\hat{o} \\
\mathrm{n}=864\end{array}$ & $\begin{array}{c}9 \text { wk } \\
\text { of age } \\
n=576\end{array}$ & $\begin{array}{c}12 \text { wk } \\
\text { of age } \\
\mathrm{n}=576\end{array}$ & $\begin{array}{c}15 \text { wk } \\
\text { of age } \\
n=576\end{array}$ & 2008 & 2009 & 2010 & 2011 \\
\hline \multicolumn{11}{|c|}{ Antioxidant parameters } \\
\hline SOD & LSM & $25.24 * *$ & $23.64 * *$ & $26.47^{\mathrm{A}}$ & $24.96^{\mathrm{B}}$ & $21.88^{\mathrm{C}}$ & $27.09^{\mathrm{A}}$ & $24.32 \mathrm{~A}^{\mathrm{B}}$ & $27.98^{\mathrm{A}}$ & $28.35^{\mathrm{A}}$ \\
\hline $\mathrm{U} / \mathrm{mL}$ & $\mathrm{SE}$ & 0.36 & 0.36 & 0.50 & 0.33 & 0.42 & 0.38 & 0.35 & 0.28 & 0.06 \\
\hline CAT & LSM & 4.15 & 4.29 & $5.09^{\mathrm{A}}$ & $3.88^{\mathrm{BC}}$ & $3.71^{\mathrm{C}}$ & $5.04^{\text {Aa }}$ & $3.71^{\mathrm{B}}$ & $4.48^{\mathrm{ABb}}$ & $3.68^{\mathrm{B}}$ \\
\hline $\mathrm{U} / \mathrm{mL}$ & $\mathrm{SE}$ & 0.11 & 0.09 & 0.13 & 0.09 & 0.13 & 0.12 & 0.15 & 0.13 & 0.15 \\
\hline \multirow{2}{*}{$\begin{array}{l}\text { FRAP } \\
\mu \mathrm{mol} / \mathrm{L}\end{array}$} & LSM & 69.46 & 68.08 & $62.85^{\mathrm{B}}$ & $75.58^{\mathrm{A}}$ & $67.88^{\mathrm{AB}}$ & $60.63^{\mathrm{B}}$ & $72.65^{\mathrm{A}}$ & $70.16^{\mathrm{A}}$ & $71.63^{\mathrm{A}}$ \\
\hline & SE & 1.27 & 0.88 & 1.51 & 1.08 & 1.24 & 1.42 & 2.58 & 0.87 & 2.05 \\
\hline VIT.C & LSM & $0.174 * *$ & $0.190 * *$ & $0.175^{\mathrm{Bb}}$ & $0.192^{\text {Aa }}$ & $0.179^{\mathrm{Bb}}$ & $0.095^{\mathrm{D}}$ & $0.186^{\mathrm{B}}$ & $0.144^{\mathrm{C}}$ & $0.303^{\mathrm{A}}$ \\
\hline $\mathrm{Mg} / \mathrm{L}$ & $\mathrm{SE}$ & 0.005 & 0.005 & 0.006 & 0.006 & 0,006 & 0.002 & 0.012 & 0.003 & 0.010 \\
\hline \multirow{2}{*}{$\begin{array}{l}\text { GSSG } \\
+\mathrm{GSH} \\
\mu \mathrm{mol} / \mathrm{L}\end{array}$} & LSM & $0.171^{* *}$ & $0.155^{* *}$ & $0.139^{\mathrm{C}}$ & $0.180^{\mathrm{A}}$ & $0.170^{\mathrm{AB}}$ & $0.165^{\mathrm{A}}$ & $0.130^{\mathrm{B}}$ & $0.226^{\mathrm{A}}$ & $0.130^{\mathrm{C}}$ \\
\hline & SE & 0.003 & 0.004 & 0.002 & 0.006 & 0.004 & 0.002 & 0.0005 & 0.0005 & 0.0004 \\
\hline \multicolumn{11}{|c|}{ Oxidative parameters } \\
\hline \multirow{2}{*}{$\begin{array}{l}\mathrm{H}_{2} \mathrm{O}_{2} \\
\mu \mathrm{mol} / \mathrm{L}\end{array}$} & LSM & $5.24 * *$ & $5.68 * *$ & $4.02^{\mathrm{B}}$ & $6.32^{\mathrm{Aa}}$ & $6.03^{\mathrm{Ab}}$ & 6.19 & 5.57 & 6.74 & 3.33 \\
\hline & SE & 0.12 & 0.09 & 0.14 & 0.11 & 0.10 & 0.15 & 0.20 & 0.07 & 0.10 \\
\hline \multirow{2}{*}{$\begin{array}{l}\text { MDA } \\
\mu \mathrm{mol} / \mathrm{L}\end{array}$} & LSM & $0.24^{* *}$ & $0.57^{* *}$ & 0.424 & 0.400 & 0.381 & $0.311^{\mathrm{B}}$ & $0.268^{\mathrm{C}}$ & $0.937^{\mathrm{A}}$ & $0.091^{\mathrm{D}}$ \\
\hline & SE & 0.01 & 0.03 & 0.039 & 0.035 & 0.032 & 0.007 & 0.012 & 0.031 & 0.013 \\
\hline
\end{tabular}

${ }^{\mathrm{a}, \mathrm{b}, \mathrm{c}}$ : means within the row with no common superscript differ significantly at $P \leq 0.05$.

$\mathrm{A}, \mathrm{B}, \mathrm{C}$ : means within the row with no common superscript differ significantly at $P \leq 0.01$.

* $(P \leq 0.05)$; ** $(P \leq 0.01)$.

SOD: superoxide dismutase; CAT: catalase; FRAP: total antioxidant potential of plasma; VIT C: vitamin C; GSSG+GSH: glutathione total, $\mathrm{H}_{2} \mathrm{O}_{2}$ : peroxides; MDA: malondialdehyde. 
followed by a decrease in the final period of rearing is likely to be owing to changes in the intensity of the oxidative stress, which is indicated by identical changes observed for hydrogen peroxide. According to observations made in experiments with poultry and humans, the reducing level of FRAP along with age is an effect of depletion of non-enzymatic antioxidants, which are FRAP constituents (glutathione in particular) (Ibrahim et al., 2000; Milinković-Tur et al., 2007; Milinković-Tur et al., 2009). Results in the present study, viz. the initial increase in glutathione level along with age, followed by a decrease, correspond with findings in a study with broiler chickens (Kamel et al., 2003).

Year of study had an impact on the values of the blood markers examined (Table 4). The four-year analysis of changes in parameters of the redox status in blood of turkeys demonstrated that a diminished level of lipid peroxidation products (MDA) resulted in the suppressed activity of the enzymes SOD and CAT, and of total glutathione, as well as increased levels of FRAP and vitamin C. These tendencies were observed in 2009 and 2011.

Table 5 Effect of interactions between sex (S), age (A), dietary antioxidant (D) and year (Y) on antioxidant and oxidative parameters in blood plasma of growing turkeys

\begin{tabular}{cccccc}
\hline \multicolumn{7}{c}{ Antioxidative parameters } \\
\hline Interactions & $\begin{array}{r}\text { SOD } \\
\text { U/mL }\end{array}$ & $\begin{array}{c}\text { CAT } \\
\text { U/mL }\end{array}$ & $\begin{array}{c}\text { FRAP } \\
\boldsymbol{\mu m o l} / \mathbf{L}\end{array}$ & $\begin{array}{c}\text { VIT.C } \\
\mathbf{m g} / \mathbf{L}\end{array}$ & $\begin{array}{c}\text { GSSG+GSH } \\
\boldsymbol{\mu m o l} / \mathbf{L}\end{array}$ \\
\hline S x A & $* *$ & $* *$ & $* *$ & $* *$ & $* *$ \\
S x D & $* *$ & $* *$ & $* *$ & $* *$ & $* *$ \\
A x D & $* *$ & $*$ & $*$ & $* *$ & $* *$ \\
D x Y & - & $* *$ & $* *$ & $* *$ & $* *$ \\
\hline
\end{tabular}

\begin{tabular}{ccc}
\hline & \multicolumn{2}{c}{ Oxidative parameters } \\
\cline { 2 - 3 } Interactions & $\begin{array}{r}\mathbf{H}_{2} \mathbf{O}_{2} \\
\boldsymbol{\mu m o l} / \mathbf{L}\end{array}$ & $\begin{array}{c}\text { MDA } \\
\boldsymbol{\mu m o l} / \mathbf{L}\end{array}$ \\
\hline $\mathrm{Y} \times \mathrm{D}$ & $* *$ & - \\
$\mathrm{S} \times \mathrm{Y}$ & $* *$ & - \\
$\mathrm{A} \times \mathrm{Y}$ & $* *$ & $* *$ \\
$\mathrm{~A} \times \mathrm{D}$ & - & $* *$
\end{tabular}

$* P \leq 0.05 ; * * P \leq 0.01$.

SOD: superoxide dismutase; CAT: catalase; FRAP: total antioxidant potential of plasma; VIT C: vitamin C; GSSG+GSH: glutathione total; $\mathrm{H}_{2} \mathrm{O}_{2}$ : peroxides; MDA: malondialdehyde.

Unfortunately, the literature lacks information on the effect of differences between years on changes in the parameters of the antioxidant status of the birds. Comparisons were not possible. It is likely that the differences in the values of the parameters that were observed in particular years in the present study result from the impact of additional factors such as differences in microclimate of the turkey houses, and stress that were not investigated in the present study, as well as multiple interactions (Table 5) observed between the factors.

\section{Conclusions}

The sex of the birds was found to determine the higher levels of peroxides, malondialdehyde and vitamin $C$ in the blood of the turkey toms. Lower activities of superoxide dismutase and glutathione were also observed in toms. The age of the birds had an effect on the reduced levels of low-molecular antioxidants (FRAP, vitamin C, GSSG+GSH) at the final period of rearing and on the successive decrease in the activities of antioxidative enzymes (SOD, CAT). The application of antioxidative or potentially antioxidative natural and synthetic additives caused an increase in the levels of FRAP and vitamin C. 
The study confirmed the hypothesis that sex, age and antioxidant supplement, whether natural or synthetic, can alter blood antioxidant status indicators in turkeys.

\section{References}

Akerboom, T.P. \& Sies, H., 1981. Assay of glutathione, glutathione disulfide, and glutathione mixed disulfides in biological samples. Meth. Enzymol. 77, 373-382.

Bartosz, G., 2004. Second face of oxygen. PWN Warszawa.

Benzie, I.F.F. \& Strain, J.J., 1996. The ferric reducing ability of plasma (FRAP) as a measure of antioxidant power the FRAP assay. Anal. Biochem. 239, 70-76.

Ehrenbrink, G., Schafer-Hakenhaar, F., Boeina, S.T., Pilla-Petrucci, A., Rodrigues, S.M. \& Silveira-Benfato, M., 2006. Antioxidant enzymes activities and protein damage in rat brain of both sexes. Exp. Life Sci. 49, 663-668.

Farahat, G.S., Eissa, E.A. \& Mézes, M., 2008a. Effect of genotype, heterosis and sex on body weight and red blood cell haemolysate and blood plasma glutathione peroxidase activity at the age of sexual maturity in chickens. J. Poult. Sci. 45, 180-185.

Farahat, G.S., Eissa, E.A., Balogh, K. \& Mézes, M., 2008b. Glutathione peroxidase activity in different breeds and sexes of chickens during embryonic development up to peak of egg production. J. Anim. Feed Sci. 17, 588-599.

Finley, J.W. \& Kincaid, R.L., 1991. Effect of sex and time of sampling on selenium and glutathione peroxidase activity in tissues of mature rats. Biol. Tr. Elem. Res. 29, 181-191.

Gay, C. \& Gębicki, J.M., 2000. A critical evaluation of the effect of sorbitol on the ferric-xylenol orange hydroperoxide assay. Anal. Biochem. 284, 217-220.

Gay, C. \& Gębicki, J.M., 2002. Perchloric acid enhances sensitivity and reproducibility of the ferric-xylenol orange peroxide assay. Anal. Biochem. 304, 42-46.

Gihan, S., Farahat, A.M., Abdel Azim, A. \& Osman, M.R., 2009. Breed differences and phenotypic correlations of antioxidant enzymes activities, some physiological parameters and productive traits of chicken. Egypt. Poult. Sci. 29, 623-644.

Godin, D., Garnett, M., Cheng, K. \& Nichols, C., 1995. Sex-related alterations in antioxidant status and susceptibility to atherosclerosis in Japanease quail. Can. J. Cardiol. 10, 945-951.

Gomez-Zubeldia, M.A., Hernandez, R., Viguera, J., Arbues, J.J., Aparicio, A. \& Millan, J.C., 2000. Effect of bilateral ovariectomy and overian steroid hormones on the antioxidant system and plasma malondialdehyde levels in Wistar rats. Endocr. Res. 26, 97-107.

Ibrahim, W.U.S., Lee, H.C., Yen, D., Stclair, K. \& Chow, C.K., 2000. Antioxidant and oxidative status in tissues of manganese superoxide dismutase transgenic mice. Free Radical Biol. Med. 3, 397-402.

Kamel, Z. \& Mahmoud, F.W., 2003. Influence of selenium sources on age-related and mild heat stressrelated hanges of blood and liver glutathione redox cycle in broiler chickens (Gallus domesticus). Compar. Biochem. Physiol. 136, 921-934.

LaVronga, M.W. \& Combs, G.F., 1982. Evidence of a hereditary factor affecting the chick's response to uncomplicated selenium deficiency. Poult. Sci. 62, 164-168.

Lutnicki, K., Szpringer, E. \& Marciniak, A., 2006. Ethanol evoked oxidation-antioxidation imbalance in rats. Medycyna Vet. 62 (6), 683-685.

Maini, S., Sunil, K.R., Jayant, P.K., Arun, K.M. \& Santosh, K.S., 2007. Evaluation of oxidative stress and its amelioration through certain antioxidants in broilers during summer. J. Poult. Sci. 44, 339-347.

Milinković-Tur, S., Stojević, Z., Pirśljin, M., Zdelar-Tuk, N., PoljiCak-Milas, B., Beer Ljubić, B. \& Gradinski-Vrbanac, B., 2007. Effect of fasting and refeeding on the antioxidant system in cockerels and pullets. Acta Vet. Hung. 55, 181-189.

Milinković-Tur, S., Aladrović, J., Beer-Ljubić, B. \& Poljičak-Milas, N., 2009. Age-related antioxidant enzyme activities and lipid peroxidation in heart muscles of broiler chickens fed with supplementary organic selenium. Vet. Arhiv. 79 (5), 481-489,

NRC, 1994: Nutrient Requirements of Poultry. National Research Council. Ninth Revised Ed. National Academy Press. Washington, D.C., USA.

Ognik, K. \& Sembratowicz, I., 2007. Influence of Biostymina and Bioaron C on some anti-oxidation and immune indices of turkey-hens' blood. Pol. J. Environ. Stud. 16 (3A), 209-212. 
Ognik, K. \& Czech, A., 2010a. The effect of diversified doses of Aloes plus planet preparation on the level of antioxidant indices in the blood of turkey hens. Appl. Anim. Res. 38, 45-48.

Ognik, K. \& Czech, A., 2010b. Wpływ dodatku koncentratu białkowo-ksantofilowego z lucerny (Medicago Sativa) na potencjał antyoksydacyjny krwi indorów. Zesz. Nauk. Pol. Tow. Zootech. 6 (3), 77-86.

Ognik, K. \& Sembratowicz, I., 2011. Influence of a newly-synthesised 5-oxo-1,2,4-triazyne derivative on antioxidant indices of blood and performance of turkey hens. S. Afr. J. Anim. Sci. 41, 403-412.

Ognik, K. \& Sembratowicz, I., 2012. Stress as a factor modifying the metabolism in poultry. Annales sec. EE. 30 (2), 34-43.

Omaye, S.T., Tumbull, J.D. \& Sauberlich, H.E., 1979. Selected methods for determination of ascorbic acid in animal cells, tissues and fluids. Meth. Enzymol. 62, 3-11.

Resolution number 9/2008 of 20 January 2008; 11/2009 of 20 January 2009-2011. Second Local Ethical Committee for Animal Xperiments in Lublin. University of Life Sciences, Akademicka 13, 20-950 Lublin, Poland.

Salih, M., Smith, D.M., Price, J.F. \& Dawson, L.E., 1987. Modified extraction 2-thiobarbituric acid method for measuring lipid oxidation in poultry. Poult. Sci. 66, 1483-1488.

SAS, 1996. Statistical Analysis Systems user’s guide. Version 6.11. SAS Institute, Inc., Cary, N.C., USA.

Serafini, M. \& Del Rio, D., 2004. Understanding the association between dietary antioxidants, redox status and disease: Is the Total Antioxidant Capacity the right tool? Redox Report 9, 145-152.

Sohal, R.S., Mockett, R.J. \& Orr, R.C., 2002. Mechanisms of aging: an appraisal of the oxidative stress hypothesis. Free Radic. Biol. Med. 33, 575-586.

Tian, L., Cai, Q. \& Wei, H., 1998. Alterations of antioxidant enzymes and oxidative damage to macromolecules in different organs of rats during aging. Free Radic. Biol. Med. 24, 1477-1484.

Truchliński, J., Ognik, K. \& Sembratowicz, I., 2007. Influence of prolonged and interrupted stress from crowding and cooling of turkey hens on anti-oxidation indices of the blood. Med. Wet. 1, 95-98.

Vara Prasad Reddy, L.S.S., Thangavel, A., Leela, V. \& Narayana Raju, K.V.S., 2009. Antioxidant enzyme status in broiler: Role of dietary supplementation of tulasi (Oscimum sanctum) and selenium. Tamilnadu J. Vet. Anim. Sci. 5 (6), 251-256.

Verma, P.K., Singh, Y., Raina, R. \& Kumar, J., 2012. Stress biomarkers in Vanaraja chicken maintained under various rearing systems. J. Advan. Vet. Res. 2, 5-8.

Wang, S., Bottje, W., Dawithon, D., Ewenson, C., Beers, K. \& Mcnew, R., 1998. Hepatic export of glutathione and uptake of constituent amino acids glutamate and cysteine, in broilers in vivo. Poult. Sci. 77, 1556-1564.

Weitzel, F., Ursini, F. \& Wendel, A., 1989. Dependence of mouse liver phospholipid hydroperoxide glutathione peroxidase on dietary selenium W. In: Selenium in Biology and Medicine. Ed.: Wendel, A., Spinger- Verlag, Berlin, 29: 33-38.

Wickens, A.P., 2001. Ageing and the free radical theory. Respir. Physiol. 128, 379-391.

Yan, H. \& Harding, J.J., 1997. Glycation-induced inactivation and loss of antigenicity of catalase and superoxide dismutase. Biochem. J. 328, 599-605. 